\title{
Communication of the origin of food products: legal aspects
}

\section{Framework of the investigation}

One of the main problems to be faced whenever the origin of an agri-food product or an ingredient is to be highlighted to consumers is a combination of sometimes conflicting interests or rules: alongside the interests of some producers in highlighting the geographical origin of their products, there are the conflicting interests of other producers who, for various reasons, would like to avoid communicating the origin of the product as much as possible; on the other hand, there is a convergence of interests among producers in ensuring that the indication of the origin of agri-food products, where permitted, is done in accordance and compliance with the regulatory framework, so as to avoid unfair competition. Last but not least, the legislation implementing the principle of the free movement of goods has a not insignificant impact on this issue, since, as we know, the indication of the origin of a product can distort the proper functioning of the internal market, insofar as it can lead consumers to prefer domestic products or, in any case, affect their purchasing choices.

In fact, the interests of producers in communicating to the public the geographical origin of their products clash both with the prohibition on measures having an effect equivalent to quantitative restrictions laid down in Article 34 TFEU, since highlighting the origin of the product may result in favouring the national ${ }^{1}$ product, as well as with the principle of mutual recognition, which is one of the cornerstones of the principle of free move-

* University of Ferrara, Italy.

${ }^{1}$ See the Dassonville judgment, 11 July 74, Ref. No 4/74 (Judgment of CJEU of 11 July 1974, Ref. No 8/74, Procureur du Roi v Benoît and Gustave Dassonville, ECLI:EU:C:1974:82), according 
ment as developed by the Court of Justice over a long period of time, since it requires all interested parties to move freely the products made within the territory of the EU, as long as they are legally manufactured, i.e. in compliance with the regulations of the Member State where production takes place; such products must circulate freely, even if - as far as agro-food products are concerned - they have been obtained with recipes or production methods that differ from those in force in the importing State, apart from the exceptions identified by the TFEU ${ }^{2}$ and by case law. ${ }^{3}$

In this context, highlighting the origin of goods tends to constitute an obstacle to marketing on the European market, since such information involves emphasizing the origin of the product, which can affect the trading in goods within the Union in a number of ways.

The mention of the origin of a product or of certain of its ingredients is, in fact, an action which inevitably has commercial repercussions, since it favours national production of a product to the detriment of similar products produced in other Member States, or in any case benefits those countries, such as Italy, in which the origin of foodstuffs sometimes significantly influences the organoleptic qualities of the product, which is more highly regarded than its counterpart elsewhere.

It is undoubtedly true that the principle of mutual recognition and the more general principle of the free movement of goods privilege the quantitative aspects to the detriment of the qualitative ones, assuming a substantial homogeneity and adequacy, as to the protection of consumers from the hygienic-sanitary point of view, of the various national systems; with regard to the qualitative aspects of the products, the protection of the consumer is entrusted to the label and, in any case, to the set of information that accompanies food products, with all the problematic profiles already widely outlined in doctrine, first of all that a large segment of consumers risks remain without adequate protection, basically because consumers do not have tools to understand the information contained in the label and in any case pay not enough attention to it.

A further corollary of the principle is, moreover, the alleged irrelevanceaccording to the Court of Justice - of any regulations that are more restrictive or, in any case, stricter, from the point of view of attention to quality, that exist

to which any commercial legislation of the Member States which is capable of hindering, directly or indirectly, actually or potentially, intra-Community trade is such legislation.

${ }^{2}$ Article 36 TFEU: grounds of public morality, public policy, public security, the protection of health of humans, animals or plants, the protection of national treasures possessing artistic, historic or archaeological value, the protection of industrial and commercial property.

${ }^{3}$ Overriding requirements of a different kind, e.g. consumer protection or fair trading, constitute an inherent limitation on Article $34 \mathrm{TFEU}$, provided that they are proportionate. 
in one or more Member States with regard to the methods of production or the ingredients that can be used in certain products: in such cases, national producers will continue to have to comply with the internal regulations, unlike producers located in other Member States who are not aware of such restrictions or limitations. This is the well-known phenomenon of so-called reverse discrimination in the name of the free movement of goods, which can only be protected under national law, given that such a diversity of applicable rules results in a breach of the principle of equality.

\section{Horizontal legislation on food information to consumers and the choices made on the origin of products: Articles 9 and 26, EU Regulation No 1169/2011}

Regarding consumer information on foodstuffs, the fundamental legal text is Regulation (EU) No 1169/2011 which, in the third recital and in Article 3(1) (which sets out the general objectives), takes into account the interests of consumers and considers the need to do so in order to allow them to make informed choices, taking into account health, economic, environmental, social and ethical considerations. At the same time, Article 3(2) makes clear the existence of interests other than those of consumers, stating that "food information law shall aim to achieve in the Union the free movement of legally produced and marketed food, taking into account, where appropriate, the need to protect the legitimate interests of producers and to promote the production of quality products."

The indication of the origin of an agri-food product has implications not only for the consumer, in view of the need for information and transparency, as well as the advantages sometimes associated with the origin and the consequent increase in the value of the product, but also for competitors, whether they produce products of the same origin or from different territories. According to recital 29, the indication of the country of origin or of the place of provenance must not mislead the consumer and must be provided on the basis of clearly defined criteria, allowing a level playing field for the industry and making it easier for consumers to understand this information.

This explains the special legal precautions that must be taken to ensure that the indication of origin is truthful and in any case complies with the legal framework, since otherwise the interests of both consumers and competitors may be unduly harmed.

In connection with these profiles, it is possible to explain the limits, the cautions and the contradictions provided for by EU Regulation 
No 1169/2011 regarding the possibility of compulsorily indicating on the label the country of origin of a pre-packaged food; on the other hand, it is different from the hypothesis of a purely optional indication, left to the interested party, of the origin of the product, which is allowed in compliance with the canons of good faith and truthfulness that distinguish communications to consumers.

With regard to the mandatory indication of the origin of the agrifood product, there are three separate provisions contained in Regulation No 1169/2011, represented by Articles 9, 26 and 39, which express all the difficulties underlying the matter, and require an activity of coordination between them. Moreover, they do not apply where there is a vertical discipline, i.e. for specific products for which the EU legislator has established the mandatory indication of origin.

Indeed, the regulation of Regulation No 1169/2011 is a lex generalis and does not affect the special rules of a vertical nature adopted by the EU legislator for certain agri-food products, for which the mandatory indication of origin is provided: this is the case of honey (Directive 2001/110/EC); fruit and vegetables (EU Regulation No 1308/2013 and EU Regulation No 543/2011); fish (EU Regulation No 1379/2013); beef and veal (EC Regulation No 1760/2000); olive oil (Regulation EC No 20/2012); eggs (Regulation EC No 589/2008); some imported meats (EC Regulation No 543/2008); wine products (EU Regulation No 1308/2013).

For the same reason, the discipline of Regulation No 1169/2011 on the mention of origin does not apply to PDO or PGI certified products, as will be explained later.

Article 9 is to be found in Chapter IV, which is dedicated to compulsory food information, and it contains a list of indications which are compulsory in the labelling of pre-packed foods (i.e. those to which the regulations apply): alongside the name of the food, the list of ingredients, the date of minimum durability or the use-by date, the net quantity, among others, there is an indication of the "country of origin" or the "place of provenance," "where provided for in Article 26" (thus letter (i) of Article 9(1)).

Art. 2 of EU Regulation No 1169/2011 provides a set of definitions, in order to avoid doubts about the interpretation of certain terms or expressions used in the regulation itself: the "place of provenance" is, therefore, any place indicated as the place where the food comes from, but which is not the "country of origin" as determined in accordance with Articles 23 to 26 of Regulation (EEC) No 2913/92, ${ }^{4}$ i.e. in accordance with customs leg-

${ }^{4}$ Then repealed and replaced by EC Regulation No 450/2008 (Community Customs Code), which in turn was repealed and replaced by EU Regulation No 952/2013 (Union Customs Code). 
islation. ${ }^{5}$ It is also specified that "the name, business name or address of the food business operator on the label shall not constitute an indication of the country of origin or place of provenance of the food within the meaning of this Regulation."

There are two areas of concern in this regard: firstly, the concept of "place of provenance" is not defined in positive terms, since the regulation merely clarifies that it is any place indicated as the place where the food comes from which is different from the country of origin as defined under customs legislation. That solution means that the concept of "place of provenance" is not defined but, on the contrary, leaves room for doubt and direction to the interested parties. Secondly, the concept of "country of origin" is borrowed from customs law which, as is well known, has its own criteria for identifying the country of origin of a product: on the basis of Article 60 of the EU Customs Code, the country of origin of goods is the country ${ }^{6}$ or territory in which the entire production cycle of the goods took place or, in the case of production cycles carried out in two or more States, the country in which the last substantial and economically justified transformation took place, resulting in the manufacture of a new product or representing an important stage in the manufacturing process. The reference to the customs legislation

5 Thus Article 2(2)(g).

${ }^{6}$ According to EU Court of Justice 12 November 2019, Ref. No 363/18, Organisation juive européenne, para. 28, the term "country" must be considered a synonym of the term "State"; in turn, the term "State" denotes a sovereign entity which exercises, within its geographical borders, the full extent of the powers recognised by international law (thus para. 29 of the judgment). Consequently, having thus delimited the concept of "country," it follows that the term "territory" designates "geographical areas which, although under the jurisdiction or international responsibility of a State, nevertheless have, in terms of international law, a status which is proper to and distinct from that of that State" (para. 31). In the present case, the Court held that it was compulsory to mention the origin of the product from the territories occupied by the State of Israel, since these territories, although part of the State of Israel, have their own international status, so that the indication of the State of Israel as the "country of origin" of these foods would constitute information likely to mislead consumers as to the true origin of the product. At the same time, since the food at issue came from an Israeli settlement located in the Occupied Territories, the Court held that it was necessary to include a reference to that fact, as the "place of origin" of the food in question, in the information to be provided to consumers: in so doing, however, the Court overturned the interpretation of Article 9 of Regulation No 1169/2011, which uses the disjunctive clause between the indication of the country of origin "or" that of the place of provenance, justifying this conclusion by referring to recitals 3 ) and 4) of the regulation, which state that the information provided to consumers must enable them to make informed choices which respect, in particular, health, economic, environmental, social and ethical considerations, and highlighting the fact that this list is not exhaustive, so that reference can be made, for the purposes of consumer protection as regards information, to considerations relating to compliance with international law. On the judgment see F. Albisinni, La Corte di giustizia e l'origine dei prodotti alimentari: un'irrisolta incertezza, "Rivista di diritto alimentare" 2020, No 3, p. 53 ff. 
on the identification of the country of origin in relation to the application of the rules on the provision of information to consumers of foodstuffs is thus inappropriate, given that such information is intended to protect interests other than those relating to the application of the various customs tariffs, and may thus mislead a consumer who has an interest in knowing where a particular foodstuff has been manufactured and with raw materials from which States. An exemplary case of the inappropriateness of the use of definitions used in customs law in the area of food information is the decision of the Court of Justice of the EU concerning mushrooms which, after having been grown in some European countries, were exported to Germany in boxes with peat and limestone, and harvested there a few days after entering the importing country. ${ }^{7}$ The Court $^{8}$ considered correct the indication of Germany as the country of origin of such mushrooms, without further explanations, since the customs legislation, as far as vegetable products are concerned, establishes that their country of origin is the one where the harvest takes place, regardless of the fact that substantial phases of production have taken place in other Member States.

Having said that, and returning to the compulsory indication of the country of origin or place of provenance, Article 9, as we have seen, imposes it only in the cases provided for by Article 26.

Paragraph 2 of the latter states that "Indication of the country of origin or place of provenance shall be mandatory:

(a) where failure to indicate this might mislead the consumer as to the true country of origin or place of provenance of the food, in particular if the information accompanying the food or the label as a whole would otherwise imply that the food has a different country of origin or place of provenance;

(b) for meat falling within the Combined Nomenclature $(\mathrm{CN})$ codes listed in Annex XI. ${ }^{9}$ The application of this point shall be subject to the adoption of the implementing acts referred to in paragraph 8 .

${ }^{7}$ See Judgment of the Court of Justice EU 4 September 2019, Ref. No 686/17, Zentrale sur Bekampfung unlauteren Wettbewerts Frankfurt am Main eV, on which see again F. Albisinni, La Corte di giustizia...

${ }^{8}$ It should be noted, however, that the Court's examination did not concern - if not marginally - the provisions of EU Regulation No 1169/2011, but the rules on the CMO in EC Regulation No 1234/07 and EU Regulation No 1308/2013: the use of customs legislation is, however, considered as a foregone conclusion for the purpose of identifying the country of origin referred to in the legislation on the common organization of agricultural markets.

9 The meat in question is pork, sheep, goat and poultry meat of heading 0105 , fresh, chilled or frozen: on this point, EU Regulation No 1337/2013 has intervened, making it compulsory to indicate only the place of rearing and slaughter but not also the place of birth. 
Paragraph 3 considers the case in which the country of origin or place of provenance of a food is indicated but is different from that of its primary ingredient: in such cases the Regulation requires (subject to the adoption of specific implementing acts) that the following be indicated:

(a) also the country of origin or the place of provenance of that primary ingredient; or

(b) the country of origin or place of provenance of the primary ingredient is indicated as being different to that of the food.

Paragraph 5 stated that "By 13 December 2014, the Commission shall submit reports to the European Parliament and the Council regarding the mandatory indication of the country of origin or place of provenance for the following foods:

(a) types of meat other than beef and those referred to in point (b) of paragraph 2;

(b) milk;

(c) milk used as an ingredient in dairy products;

(d) unprocessed foods;

(e) single ingredient products;

(f) ingredients that represent more than $50 \%$ of a food."

According to paragraph 6, the Commission should have submitted a report to the European Parliament and the Council by 13 December 2013 on the mandatory indication of the country of origin or place of provenance for meat used as an ingredient. ${ }^{10}$

As for the "primary ingredient," it is defined in the Regulation as "an ingredient or ingredients of a food that represent more than $50 \%$ of that food or which are usually associated with the name of the food by the consumer and for which in most cases a quantitative indication is required."

${ }^{10}$ The following paragraphs provide: " 7 . The reports referred to in paragraphs 5 and 6 shall take into account the need for the consumer to be informed, the feasibility of providing the mandatory indication of the country of origin or place of provenance and an analysis of the costs and benefits of the introduction of such measures, including the legal impact on the internal market and the impact on international trade. The Commission may accompany those reports with proposals to modify the relevant Union provisions.

8. By 13 December 2013, following impact assessments, the Commission shall adopt implementing acts concerning the application of point (b) of paragraph 2 of this Article and the application of paragraph 3 of this Article. Those implementing acts shall be adopted in accordance with the examination procedure referred to in Article 48(2).

9. In the case of foods referred to in point (b) of paragraph 2, in point (a) of paragraph 5 and in paragraph 6, the reports and the impact assessments under this Article shall consider, inter alia, the options for the modalities of expressing the country of origin or place of provenance of those foods, in particular with respect to each of the following determining points in the life of the animal:(a) place of birth; (b) place of rearing; (c) place of slaughter. 
According to the definition, therefore, a food can have two primary ingredients: one identified on the basis of quantitative aspects (constituting more than $50 \%$ of the ingredients) and one on the basis of abstractly qualitative profiles but not free from subjective elements and not always easy to ascertain (the association by the consumer with the name of the food).

According to the combined provisions of Articles 9 and 26, therefore, the mandatory indication of the country of origin or place of provenance is required where its omission might cause the consumer to be misled as to the true origin of the product.

This point alone highlights the tortuous nature of the application of the provisions in question, insofar as the mandatory nature of an indication is prescribed only when the omission of such an indication could mislead the consumer as to the identification of the origin of a foodstuff. It should also be borne in mind that the concept of origin itself is not free from critical issues, as we have tried to highlight above. Even with regard to the presence of a primary ingredient, the situation does not seem much better, in light of the breadth of the definition and the interpretative difficulties mentioned above, without considering that the implementing regulation on this point was adopted only in 2018 (see EU Regulation No. 2018/775).

And all this is without mentioning the fact that, despite the provisions of Article 26(5), the Commission has still not submitted the required reports on the mandatory indication of origin for certain categories of foodstuffs, including milk and milk products.

So much so that this has allowed some States, including Italy, to adopt their own measures regarding the compulsory nature of the indication, making use of the last of the three articles referred to above, i.e. Article 39.

\section{The further hypotheses of a mandatory mention of the origin of products following national measures: Articles 38 and 39, EU Regulation No 1169/2011, as interpreted by the Court of Justice in the Lactalis judgment}

Chapter VI of EU Regulation No 1169/2011 is dedicated to the "National measures": the first of the articles of which the Chapter is composed is Article 38, composed of two paragraphs: according to paragraph 1, "As regards the matters expressly harmonised by this Regulation, Member States may not adopt nor maintain national measures unless authorised by Union law. Those national measures shall not give rise to obstacles to free movement of goods, including discrimination as regard foods from other Member States;" 
paragraph 2 states that "Without prejudice to Article 39, Member States may adopt national measures concerning matters not specifically harmonised by this Regulation provided that they do not prohibit, impede or restrict the free movement of goods that are in conformity with this Regulation."

Paragraph 1 shows that not the entire sector of food information to consumers should be considered harmonised under Regulation No 1169/2011, so that there is still room for manoeuvre for Member States, provided that the principle of free movement of goods is not interfered with.

The following Article, in its 1st paragraph, allows Member States to adopt provisions to impose additional mandatory particulars for specific types or categories of foods ${ }^{11}$ on the basis of grounds of: a) protection of public health; b) protection of consumers; c) prevention of fraud; d) protection of industrial and commercial property rights, indications of provenance, registered designations of origin and prevention of unfair competition.

With specific reference to mandatory origin labelling, paragraph 2 further states that "By means of paragraph 1, Member States may introduce measures concerning the mandatory indication of the country of origin or place of provenance of foods only where there is a proven link between certain qualities of the food and its origin or provenance. When notifying such measures to the Commission, Member States shall provide evidence that the majority of consumers attach significant value to the provision of that information."

This allows Member States to provide for additional cases of mandatory origin labelling, provided they can demonstrate a "proven" link between certain qualities of the food and its origin or provenance, and provide evidence that the majority of consumers attach a "significant" value to the provision of such claims.

There is no one who does not see the tortuous nature of the provisions referred to, the result, once again, of that set of conflicting interests mentioned at the beginning of this work.

The fact is that, as mentioned, Italy - like other countries - has taken advantage of these provisions to adopt, on an "experimental" basis, measures that have imposed the mandatory indication of origin for certain products such as milk and dairy products, rice, durum wheat for pasta, tomatoes.

${ }^{11}$ Textually: "In addition to the mandatory particulars referred to in Article 9(1) and in Article 10, Member States may, in accordance with the procedure laid down in Article 45, adopt measures requiring additional mandatory particulars for specific types or categories of foods, justified on grounds of at least one of the following: (a) the protection of public health; (b) the protection of consumers; (c) the prevention of fraud; (d) the protection of industrial and commercial property rights, indications of provenance, registered designations of origin and prevention of unfair competition." 
For example, DM (Ministerial Decree) of 6 August 2020, ${ }^{12}$ which establishes the mandatory indication of the place of origin on the label of processed pork, applicable until 31 December 2021; DM of 1 April 2020, which extended to 31 December 2021 (compared to the original deadline of 31 December 2020) the mandatory indication on the label of the origin of durum wheat for pasta, of rice and of tomato derivatives; to the Ministerial Decree of 22 July 2020, which extended the mandatory indication of the country of origin of the raw material for milk and dairy products until 31 December 2021. ${ }^{13}$

Formally, the aforementioned ministerial decrees are still in force: however, it remains to be assessed whether they are compatible with EU law in relation to the interpretation offered by the Court of Justice in the Groupe Lactalis case, which will be discussed shortly, but also with regard to the adoption of EU Implementing Regulation No 2018/775, applicable from 1 April 2020, which contains the EU rules on the mandatory indication of origin in the presence of a primary ingredient obtained in a different country. ${ }^{14}$

An important clarification on the provisions now referred to has recently come from the EU Court of Justice, called to give a preliminary ruling within a dispute in which the Lactalis group challenged before the French Conseil d'Etat the decree of 19 August 2016 that imposed, on a "provisional" basis, a term from 1 January 2017 until 31 December 2018, subsequently extended to 31 December 2021, which France had also adopted to make mandatory the indication of the country of farming and the country of processing of milk and cheese.

With the judgment of 1 October 2020, in case C-485/18, the Court ruled that: a) Regulation No 1169/2011 expressly harmonises (thus limiting the powers of Member States by virtue of the provisions of Article 38, paragraph 1, of Regulation No 1169/2011) the matter of the indication of the country of origin or place of provenance of foods in cases where the omission of such indication might mislead the consumer; b) Regulation No 1169/2011 does not, however, expressly harmonise other cases or situations. Consequently, under Article 39 of Regulation No 1169/2011, the Member States may introduce additional mandatory particulars for certain types or categories of food (and not for all food without distinction), including an indication of the country of origin or place of provenance, in circumstances other than those

12 In Official Gazette No 230 of 16 September 2020.

${ }_{13}$ Previously, it provided for DM of 9 December 2016, until 31 March 2019, and then DM of 18 March 2019, which was effective until 31 March 2020.

${ }_{14}$ V. Rubino, Sulle ragioni dell'incoerenza tra il dire e il fare: l'indicazione dell'origine degli alimenti, il mercato interno e il regolamento di esecuzione della Commissione (UE) n. 2018/775, "Diritto Agroalimentare" 2019, No 2, p. 319 ff. 
in which failure to give such an indication might mislead the consumer, provided that they are compatible with the objective pursued by the European Union legislator ( $1^{\text {st }}$ question); (c) Article 39(2) lays down not one but two distinct requirements to enable States to make origin information mandatory, namely (i) the existence of a proven link between certain qualities of certain foods and their place of origin or provenance, and (ii) the proof that the majority of consumers attach significant value to the provision of that information. In particular, the fulfilment of condition (ii) must be established only after the fulfilment of condition (i) has been positively established. In the Court's view, that solution is also justified on the basis of considerations of a systematic nature, recalling for that purpose the provisions of Article 7 of the regulation on fair information, considering it inadmissible to make the mandatory introduction of information attributable to purely subjective aspects and not even when there are objective links between the origin and quality of the food ( $2^{\text {nd }}$ question); (d) Article 39(2), when it refers to "quality," refers to the qualities which distinguish foods which possess them from similar foods which, having a different origin or provenance, do not possess them (paragraph 50). The ability of the food to withstand transport and the risk of deterioration during transport does not constitute such a quality, since that quality may be possessed irrespective of its origin ( $3^{\text {rd }}$ question).

Following that judgment, the French Conseil d'Etat annulled the contested decree on 10 March 2021, having evidently found it lacking the conditions required by Article 39(2).

It is no coincidence that the appeal was brought by Groupe Lactalis, a milk and cheese producer (owner, for example, of the Galbani, Vallelata, Invernizzi, Cademartori and Locatelli brands in Italy alone) with a turnover in the billions ( 18.5 billion euros), 80,000 employees and 250 factories in 50 countries: it did not take a favourable view of a measure such as the one under appeal, which, by requiring the indication of the country of rearing and the country of processing of milk and cheese, was seen as an obstacle to the movement of its products in the internal market.

\section{The indication of origin in organic farming products and in PDO and PGI products}

In the European system, however, there are further regulatory tools that allow to highlight the geographical origin of food products and to distinguish the production obtained from the "ordinary" one: this is the discipline on quality food products, substantiated in EU Regulation 
No 1151/2012 on products with protected designation of origin or protected geographical indication, and in EC Regulation No 834/2007 on organic farming products.

As for the latter, the indication of the origin of the product is compulsory, according to Article 24, Regulation No 834/2007, which imposes, for pre-packaged products, the indication of the place where the agricultural raw materials have been cultivated in terms of "EU/non-EU agriculture;" this is, as it is evident, a rather tenuous indication, as far as the actual origin of the raw material is concerned, but the regulation specifies that "The above-mentioned indication 'EU' or 'non-EU' may be replaced or supplemented by a country in the case where all agricultural raw materials of which the product is composed have been farmed in that country;" similarly, Article 32, EU Regulation No 2018/848, which is intended to replace the now existing Regulation No 834/2007 with effect from 1 January 2022. ${ }^{15}$

Much more attention to the place of production is given, instead, by the discipline on PDO or PGI products, articulated in different regulations, each one having as object distinct products: the EU Regulation No 1151/2012 deals, in fact, with agri-food products, but it is joined by EU Regulation No 1308/2013 for wines, EU Regulation No 2019/787 for spirits and EU Regulation No 251/2014 for aromatised wines.

This is certainly not the place to examine the regulations in question in detail: it is sufficient to note here that the characteristic that distinguishes PDO or PGI products from the corresponding ordinary products is precisely the link between the qualities of the product and the place of origin, so that the latter assumes a decisive role for the product, making its communication to the consumer essential. ${ }^{16}$

Products with a denomination of origin also benefit from an important instrument of protection against counterfeiting, imitations and evocations, in order to avoid the phenomena of illegal competition, created by those who appropriate the denomination without having the right to do so.

The logic underlying the regulation of products with denomination of origin is different from that of trademarks, whether individual or collective, since anyone can, in principle, use the denomination as long as the relative production regulations can be respected. On the contrary, the law of trademarks moves from a perspective strictly anchored to the right of ownership,

15 V.E. Cristiani, I prodotti dell'agricoltura biologica, in: P. Borghi, I. Canfora, A. Di Lauro, L. Russo (eds.), Trattato di diritto alimentare, Milan 2021.

${ }^{16}$ In doctrine, for all, see M. Libertini, L'informazione sull'origine dei prodotti nella disciplina comunitaria, "Rivista di diritto industriale" 2010, vol. I, p. 289 ff.; A. Di Lauro, Le Denominazioni d'origine protette (DOP) e le Indicazioni geografiche protette (IGP), in: P. Borghi, I. Canfora, A. Di Lauro, L. Russo (eds.), Trattato... 
so that a trademark can be legitimately used only by its owner or by whoever has been authorized by the owner himself.

Recognition of the designation of origin means that the products benefiting from it are assimilated to those covered by industrial property rights: in this way, quality products remain outside the application of the principle of mutual recognition and the associated tendency to ignore the place of production.

It is true that, although important especially for Mediterranean countries, these are still niche products, even if organic agriculture is destined to increase its market share significantly, in light of the objectives set by the Commission with the Communication "From Farm to Fork," which proposes to have at least $25 \%$ of European farmland devoted to organic production by 2030 .

Beyond the discipline, it is important to note that the use of the instrument of the denomination of origin has probably been excessive, perhaps also because of the width of the legislation: it is enough to think of the extraordinary number of Italian products that have obtained the PDO or PGI certification (310 as of April 2021, excluding wines), even with regard to products that are essentially only local, for which the use of a collective geographic brand or a national geographic certification ${ }^{17}$ brand would probably have been sufficient and more appropriate.

\section{The geographic origin of the product and brands (individual, collective, certification)}

The geographical origin of a product can also be highlighted by means of a trademark. It is well known that it is forbidden for individual trademarks to contain references to the geographical origin of the product"18; despite this limitation, however, in some cases even individual trademarks, if particularly strong and appreciated on the market, can allow not only an association between the product and the place of production, but also between the quality of the product and its geographical origin, even in the absence of quality certifications. If it is true, in fact, that the trademark itself does not express

${ }^{17}$ Consider that the "Qualivita" body has compiled a ranking of the top 10 Italian PDO and PGI products by production value; these are, in order of importance: Grana Padano DOP, Parmigiano Reggiano DOP; Prosciutto di Parma DOP; Aceto Balsamico di Modena IGP; Mozzarella di Bufala Campana DOP; Mortadella Bologna IGP; Gorgonzola DOP; Prosciutto San Daniele DOP; Pecorino Romano DOP; Bresaola della Valtellina IGP. These products alone account for $79 \%$ of the total value of all the Italian certified products, excluding wines.

${ }_{18}$ Pursuant to Article 13, par. 1, I.C.P., it is forbidden to register trademarks whose signs consist exclusively of, among other things, the geographical origin of the product or service. 
a quality but a belonging, in a mediated way the authoritativeness and the seriousness of the producer to whom the trademark belongs may translate into a guarantee of quality. ${ }^{19}$

However, the geographical origin of the product can appear in collective and certification marks, with a series of precautions provided for by the relative discipline, which is composite, since there are EU regulations on EU marks, whether individual, collective or certification, and internal regulations on domestic collective and certification marks, which, in turn, operate within a harmonized framework.

In particular, the normative sources that are taken into consideration are EU Regulation No 2017/1001 which regulates EU individual, collective and certification trademarks; EU Directive 2015/2436 whose function is to harmonize the regulations of the Member States on national trademarks; and - as regards for Italy - the Industrial Property Code (IPC) ${ }^{20}$ which regulates internal trademarks.

On this basis, it is possible to examine in more detail the possibilities offered by the legislation for indicating the geographical origin of a product in a mark other than an individual mark.

Unlike individual trademarks, national collective trademarks (now owned only by public bodies or associations) may contain (thus Article 11, d. lgs. 30/2005) signs and indications to designate the geographical origin of the goods or services, by way of derogation from Article 13, para. 1, Legislative Decree 30/2005 (prohibiting the use of references about the geographical origin of the product in the individual marks); Article 74, EU Regulation No 2017/1001 provides for EU collective trademarks in the same sense. As a balance to this possibility, all producers in the geographical area concerned are however entitled to make use of the collective mark and to become members of the trade association owning the mark, provided that all the requirements set out in the regulation are met. The content of the collective mark is governed by the principle of truthfulness, so that it attests to the fact that the product comes from one of the members and from the geographical area, if any, indicated in the mark; in the light of the presence of the certification mark, it does not appear possible for the collective mark also to perform a guarantee or quality function, functions which are now entrusted to the certification mark.

According to domestic legislation, the national certification mark (in the ownership of entities carrying out certification activities for products or

19 Thus F. Albisinni, Marchi e prodotti alimentari, in: P. Borghi, I. Canfora, A. Di Lauro, L. Russo (eds.), Trattato...

${ }^{20}$ Legislative Decree No 30/2005. 
services) can also be used to guarantee the origin of a product: in this sense, Article 11-bis, I.C.P., provides for that. ${ }^{21}$ It must be highlighted, however, that pursuant to Article 83, EU Regulation No 2017/1001 on the EU trademark, the EU certification mark cannot be used to certify the geographical origin of goods, and this prohibition is evidently to prevent overlaps with the discipline relating to PDO and PGI. ${ }^{22}$

In both cases, it is established that the owner of the collective or certification "geographic" trademark cannot prevent third parties from using the geographic name which is the subject of it in a way which conforms to professional correctness (thus Article 11, para. 4, I.C.P., and Article 11-bis, para. 4, I.C.P.).

It is also possible to refuse registration if the mark is likely to create situations of unjustified privilege or otherwise prejudice the development of similar initiatives in the region.

Moreover, the Italian legislation omits any specification of the functions of collective and certification marks, giving central importance to the person entitled to submit the application, and this is contrary to Directive 2015/2436, which diversifies the functions of the two marks (collective and certification) and enhances their respective functions.

Indeed, the Italian legislation also contemplates a further trademark right, such as the "historical trademark of national interest," governed by Article 11-ter of the I.C.P..$^{23}$ for which a special register is provided listing owners of trademarks registered for at least 50 years or for whom it is possible to demonstrate a continuous use of the trademark for at least 50 years in the marketing of products or services realized in a national productive enterprise of excellence "historically connected to the national territory." It seems clear that this tool can also be used to promote a product for its connection with the territory, even if the wording of the rule seems to refer to a generic connection with the Italian territory, and not to specific locations.

It is, however, a fact that, the new Articles 11-bis and 11-ter I.C.P. on certification trademarks and historical trademarks of national interest, which are added to the previous regulations on collective trademarks, limit the effects of the prohibition, as per Article 13, par. 1, I.C.P., to register signs relating to geographical origin as trademarks.

${ }^{21}$ That article has been introduced in the I.C.P. by Article 4, Legislative Decree No 15/2019, on the basis of the possibility offered by Article 28, par. 4, Directive 2015/2436, to approximate the laws of the Member States relating to trade marks.

${ }^{22}$ M. Libertini, Collective marks and certification marks. Functions and problems of the discipline of distinctive signs of collective use, "Rivista di diritto industriale" 2019, vol. I, p. $466 \mathrm{ff}$.

${ }^{23}$ Introduced by the law decree No 34/2019, converted in law No 58/2019. 
In addition to the above, it must be added that according to the provisions of Article 19 I.C.P. State administrations and the Regions, Provinces and Municipalities can obtain trademark registrations "also having as their object distinctive graphic elements taken from the cultural, historical, architectural or environmental heritage of the relative territory," with the consequent possible licenses for use.

On the subject of regional brands, Article 29 of EU Regulation No $1151 / 2012$, according to which regional brands can be included among the optional quality indications, is also taken into consideration.

The frame, as we can see, is extremely composite, not to say confused, in light of the lack of clarity that exists, at least at the national level, between the various trademarks other than individual ones and about the possibility, offered by both national and European legislators, of having regional trademarks that to some extent can highlight the territorial origin of products.

Despite the possible points of contact, there are differences between DOP and IGP certifications on the one hand, and national certification marks on the other hand, as well as the ownership logic which certification marks, like any other mark, are based on: not only there is a different procedure to obtain the certification or the mark, but in the regulation of the certification mark (as well as in the collective one) the profile of the qualitative link between product and territory of origin is missing. Furthermore, the control systems are different and the mechanisms for accessing the denomination are different, since in order to legitimately use a trademark, even if it is a collective or certification trademark, an application must be presented by those interested.

Having said that, it is in any case clear that there may be interference between national certification marks and PDO or PGI certifications, with the consequent risk of confusion for consumers, who already have a rather confused picture based solely on the rules on products with designation of origin. In this regard, it is enough to think of the case of "mozzarella," which can be at the same time a common food, a traditional specialty guaranteed (TSG) mozzarella or two different PDO mozzarellas (buffalo mozzarella from Campania ${ }^{24}$ and Gioia del Colle mozzarella, ${ }^{25}$ entered in the register with the recent implementing Regulation EU No 2020/2018 of 9 December 2020).

Moreover, PDOs and PGIs can be also registered as collective brands,${ }^{26}$ it being understood that the owner of the collective brand will have to allow its use to all the producers of the typical area complying with the production rules.

\footnotetext{
${ }^{24}$ The product is "Mozzarella di bufala campana."

${ }^{25}$ The exact denomination is "Mozzarella di Gioia del Colle."

${ }^{26}$ Thus Article 53(16) of Law No 128/98, as replaced by Article 14 of Law No 526/1999.
} 


\title{
BIBLIOGRAPHY
}

Albisinni F. (2021), Marchi e prodotti alimentari, in: P. Borghi, I. Canfora, A. Di Lauro, L. Russo (eds.), Trattato di diritto alimentare, Milan.

Albisinni F. (2020), La Corte di giustizia e l'origine dei prodotti alimentari: un'irrisolta incertezza, "Rivista di diritto alimentare" No 3.

Cristiani E. (2021), I prodotti dell'agricoltura biologica, in: P. Borghi, I. Canfora, A. Di Lauro, L. Russo (eds.), Trattato di diritto alimentare, Milan.

Di Lauro A. (2021), Le Denominazioni d'origine protette (DOP) e le Indicazioni geografiche protette (IGP), in: P. Borghi, I. Canfora, A. Di Lauro, L. Russo (eds.), Trattato di diritto alimentare, Milan.

Libertini M. (2010), L'informazione sull'origine dei prodotti nella disciplina comunitaria, "Rivista di diritto industriale" vol. I.

Libertini M. (2019), Collective marks and certification marks. Functions and problems of the discipline of distinctive signs of collective use, "Rivista di diritto industriale" vol. I.

Rubino V. (2019), Sulle ragioni dell'incoerenza tra il dire e il fare: l'indicazione dell'origine degli alimenti, il mercato interno e il regolamento di esecuzione della Commissione (UE) n. 2018/775, "Diritto Agroalimentare" No 2.

\section{COMMUNICATION OF THE ORIGIN OF FOOD PRODUCTS: LEGAL ASPECTS}

\author{
Summary
}

The interests that revolve around the mandatory indication of the place of origin of a food product are multiple and often conflicting with each other. Alongside the interests of some producers wishing to highlight the geographical origin of their products, there are conflicting interests of other producers who, for different reasons, prefer not to disclose the origin of their product. Then there are also interests of consumers interested at receiving an ever greater and transparency of the extensive information on the product offered. The indication of the origin of a food product can also constitute an element that has an impact on the proper functioning of the internal market to the extent that it can ultimately induce consumers to purchase national products or, at least, it may affect their purchasing choices: it is therefore necessary to assess the compatibility of the mandatory indication of the origin of the food with the principle of the free movement of goods. This competition of interests explains why the European Union's legislation on this point is somewhat ambiguous: this paper, apart from the presentation of collective marks and certification marks which, although in a limited way, may contain references to the geographical origin of the products, points out to the provisions contained in Regulation EU 1169/2011 on the provision of food information to consumers, as well as the provisions regulating the products with PDO and PGI certificates.

Keywords: information to consumer of foodstuffs, origin of food, country of origin, place of provenance, mandatory labelling, certification marks, collective marks, protected designation of origin, protected geographical indications 


\title{
INFORMAZIONI SULL'ORIGINE DEI PRODOTTI ALIMENTARI - ASPETTI GIURIDICI
}

\author{
Riassunto
}

Gli interessi che ruotano attorno all'indicazione obbligatoria del luogo di origine di un alimento sono molteplici e spesso conflittuali tra loro. Accanto agli interessi di alcuni produttori interessati ad evidenziare l'origine geografica dei loro prodotti, vi sono, infatti, interessi contrastanti di altri produttori che, per ragioni opposte, preferiscono invece non divulgare la provenienza del loro prodotto. Ci sono poi gli interessi dei consumatori, che mirano ad avere una sempre maggiore trasparenza e ampiezza delle informazioni fornite loro sul prodotto offerto. Indicare l'origine di un prodotto alimentare può anche costituire un elemento che incide sul corretto funzionamento del mercato interno, nella misura in cui è possibile indurre i consumatori ad acquistare prodotti preferibilmente nazionali o comunque incidere sulle loro scelte di acquisto: occorre quindi valutare la compatibilità tra l'indicazione obbligatoria dell'origine dell'alimento con il principio di libera circolazione delle merci. Questo conflitto fra interessi concorrenziali spiega perché la legislazione dell'Unione Europea di riferimento presenti elementi di ambiguità: l'articolo presenta, oltre alle disposizioni che disciplinano i marchi collettivi e i marchi di certificazione che, pur con alcune limitazioni, possono contenere riferimenti all'origine geografica dei prodotti, anche le disposizioni del Regolamento UE 1169/2011 relativo alla fornitura di informazioni sugli alimenti ai consumatori, e la disciplina in materia di prodotti certificati IGP e DOP.

Parole chiave: informazioni fornite al consumatore dei prodotti alimentari, origine degli alimenti, paese di origine, luogo d'origine, etichettatura obbligatoria, marchi di certificazione, marchi collettivi, denominazione di origine protetta, indicazione geografica protetta 